\title{
Stress and Its Management
}

\section{Joseph Onyebuchukwu Idoko ${ }^{*}$, Benedict Chico Emerenwa Agoha², Adeniyi Sholarin Muyiwa², Adekunle A. Oyeyemi1}

\author{
${ }^{1}$ Counselling Centre, Covenant University, Ota, Nigeria \\ ${ }^{2}$ Department of Psychology, School of Human Resource Development, College of Leadership \& Development \\ Studies, Covenant University, Ota, Nigeria \\ Email: "joseph.idoko@covenantuniversity.edu.ng, ben.agoha@covenantuniversity.edu.ng, \\ solarinadeniyi@gmail.com, adeoyeyemi@yahoo.com
}

Received 7 December 2015; accepted 21 December 2015; published 25 December 2015

Copyright (C) 2015 by authors and OALib.

This work is licensed under the Creative Commons Attribution International License (CC BY).

http://creativecommons.org/licenses/by/4.0/

\section{(c) (i) Open Access}

\begin{abstract}
Stress is not a useful term for scientist because it is such a highly subjective phenomenon that has no single definition. It is always seen from a physicist and psychological perspective. Stress is a Latin word "stringer", meaning to draw tight and it was used in the 17th century to describe hardships and afflictions. By 18th century stress denoted force, pressure strain or strong efforts referring primarily to an individual producing strain. Profounder of this view indicates that an individual's stress level can be measured the same way we can measure physical strain upon a machine. Stress based on this perspective looks at stress as an outside stimulus.
\end{abstract}

\section{Keywords}

\section{Stress, Symptoms, Management}

Subject Areas: Psychology

\section{What Is Stress?}

Stress is not a useful term for scientist because it is such a highly subjective phenomenon that has no single definition. It is always seen from a physicist and psychological perspective.

Stress is a Latin word "stringer", meaning to draw tight and it was used in the 17th century to describe hardships and afflictions. By 18th century stress denoted force, pressure strain or strong efforts referring primarily to an individual producing strain. Profounder of this view indicates that an individual's stress level can be measured the same way we can measure physical strain upon a machine. Stress based on this perspective looks at stress as an outside stimulus.

Another school of thought defines stress as a person's response to a disturbance. Walter B. Cannon (1930) studied the effects on animals and persons he found out more about the "fight or flight" response [1] [2]. He

${ }^{*}$ Corresponding author. 
found out that animals and people in responding to this will choose either to stay and fight or try to escape when confronted with danger. Cannon observed that when his subjects experienced situation like fear and excitement, he decked physiological changes such as emergency adrenalin secretions. He described this individual as being under stress [1] [3].

Hansselye (1946) explained stress in three stages model.

1) ALARM REACTION: lowered resistance is followed by counter shock, an individual "defiance mechanism" becomes active.

2) RESISTANCE: the stage of maximums adaptation and hopefully, successfully return to equilibrium for the individual.

3) EXHAUSTION: when adaptive mechanism collapses a result of the stress agent containing the following researches defines stress from another perspective. Richard S. Lazarus (1970) defines stress on how the person/ appraises (constantly/unconsciously) [1] [4].

\section{The Presence of a Harmful, Threatening or Challenging Event}

Tom Cox (1970) also rejected the idea of looking at stress as simply either environmental pressure or as physiological responses. Tom and his fellow researchers suggest that stress can be best understood as part of a complex and dynamic system of transaction between the person and his environment.

Stress is subjective and relative, something that may be stressful for one person may not be stressful for another. Stress can affect your physical health, your mental health and your behavior. We cannot eliminate bad stress from our lives, we can only learn to avoid and manage it [4]-[6].

\section{Types of Stress}

Stress management can be complicated and confusing because there are different types of stress, there is need to understand this because each has its own characteristics, symptoms, duration and treatment approach. Let's look at each one.

ACUTE STRESS: This is the most common form of stress. It comes from demands and pressure of the recent past and anticipated demands and pressures of the near future. It is a laundry list of what has gone awry in their lives. The auto accident that crumpled the car fender, the loss of an important contract, rushing to meet a deadline, and handling one's child's occasional problems at school, Acute stress lasts for a short term because of this it do not have enough time to do extensive damage. Its symptoms are recognized by most people. Acute stress can crop up in anyone's life but the consolation is that it is highly treatable and manageable [1] [7].

EPISODIC ACUTE STRESS/TIME STRESS: These involves those that suffer acute stress frequently, their lives are so disorganized that they are always in chaos and crisis. They are always in a rush, but always late if something can go wrong it does. They take on too much, have too many irons in the fire, and can't organize the slew of self inflicted demands and pressures clamoring for their attention. People who are in this category describe themselves as having "a lot of nervous energy, always in a hurry, they tend to be abrupt and sometimes their irritability comes across as hostility. Their interpersonal relationships deteriorate rapidly when others respond with real hostility. Sufferers of episodic acute stress are called "worry warts" they see disaster around every corner and pessimistically predict catastrophe in every situation. They see the world as dangerous, unrewarding and punitive place where something awful is always about to happen. Individuals here see nothing wrong with their life style; they blame their woes on other people and external events.

One experiences time stress when you worry about time. You worry about the number of things that you have to do within a given time. You feel trapped, unhappy and hopeless if you fail to achieve something important. Common examples of time stress include worrying about deadlines, rushing to avoid being late for a meeting or office [8] [9].

CHRONIC STRESS: This is grinding stress that wears people away day after day and year after year. Chronic stress destroys bodies, minds and lives. It wreaks havoc through long-term attrition. It is the stress of poverty, dysfunctional families, being trapped in an unhappy marriage, in a despised job or career and ethnic endless rivalries [10].

Chronic stress comes when a person do not see a way out of miserable situation. It is the stress of unrelenting demands and pressures for seemingly interminable periods of time, with no hope the individuals' gives up searching for solutions. Some chronic stresses stem from traumatic, early childhood experiences that become 
internalized and remain forever and painful and present. The worst aspect of chronic stress is that people get used to it. They forget that it is there. Chronic stress kills through suicide, violence, heart attack, stroke and cancer. People wear down to a final, fatal breakdown. Because physical and mental resources are depleted through long-term attrition, the symptoms of chronic stress are difficult to treat and may require extended medical as well as behavioral-treatment and stress management.

ANTICIPATORY STRESS: This stress as the name implies concerns the future. This can be focused on a specific event, such as an upcoming presentation that you are going to give, marriage/wedding ceremony that is coming up. It is vague and un identified, there is an overall dread and worry about the future that something may go wrong [9] [11].

SITUATIONAL STRESS: This happens when you are in a scary situation that you do not have control over. It could be an emergency or confrontation. It is a situation that involves conflict, loss of status or getting laid off because of a mistake in the office, and losing acceptance in the eyes of your group [7] [9].

ENCOUNTER STRESS: Encounter stress revolves around people. It happens when you worry about interactions with certain person or group of people you do not like or you think that they are unpredictable. Encounter stress occurs if your role involves a lot of personal interactions with customers and clients, like Bank marketers while looking for a customer that will deposit \#50,000,000 = (fifty million naira) [9] [12].

EUSTRESS: Eustress is a positive type of stress that is short-term. It is activated when a person needs to have some extra energy or inspiration. Eustress gives us the motivation we need to win or perform excellently in a competition, exam, promotion and giving a speech [11] [13].

HYPERSTRESS: This happens when a person is forced to perform above their normal capacity. In these recent times that downsizing is taking place in many organizations many people feel stressed out due to heavy workloads. One person doing the work of ten persons. A person experiencing this type of stress can find that their emotions run higher and a smallest event can trigger a highly emotional outbreak [9] [14].

BEARSTRESS: Bear stress happens when a person is constantly agitated. Someone in a highly challenging, cognitive tasking and demanding job. This occurs when a person's potential is been overstretched [9] [15].

Psychological Stress: Psychological stress tends to be caused by emotional stressors. Emotional stressors can be caused by a genuine emotional issue, such as the death of a loved one, or such stress can be caused by a perceived emotional situation, such as a fear that you are on the chopping block at work. Either way, the stress itself is real and the problems such stress can cause are also extremely real [2] [16].

Physiological Stress: Physiological stress is stress that is caused by a real or perceived physical threat to our person. Again, even if the stress is caused by a perceived threat, the stress itself is real enough and the damage that the stress can cause over a prolonged period is also quite real [14] [17].

\section{Symptoms of the Above Discussed Types of Stress}

The signs and symptoms from stress tend to progress through several phases or stages. The more signs and symptoms a person experiences at a particular point in time the closer he/she is to stress explosion, be on guard to avoid crashing. The phases can be described as below [6] [18]:

\begin{tabular}{|c|c|c|}
\hline & Signs/Symptoms & Action \\
\hline $\begin{array}{l}\text { Phase 1-Warning } \\
\text { Early warning signs are often } \\
\text { more emotional than physica } \\
\text { and may take a year or more } \\
\text { before they are noticeable. }\end{array}$ & $\begin{array}{l}\text { - feelings of vague anxiety } \\
\text { - depression } \\
\text { - boredom } \\
\text { - } \text { apathy } \\
\text { - emotional fatigue }\end{array}$ & $\begin{array}{l}\text { - talking about feelings } \\
\text { - taking a vacation } \\
\text { - making a change from } \\
\text { regular activities } \\
\text { - taking time for yourself }\end{array}$ \\
\hline $\begin{array}{l}\text { Phase 2-Mild Symptoms } \\
\text { Warning signs have progressed } \\
\text { and intensified. Over a period } \\
\text { of } 6 \text { to } 18 \text { months, physical } \\
\text { signs may also be evident. }\end{array}$ & $\begin{array}{l}\text { - } \text { sleep disturbances } \\
\text { - more frequent headaches/colds } \\
\text { - } \text { muscle aches } \\
\text { - intensified physical and emotional fatigue } \\
\text { - withdrawal from contact with others } \\
\text { - irritability } \\
\text { - intensified depression }\end{array}$ & $\begin{array}{l}\text { - more aggressive lifestyle } \\
\text { changes may be needed. } \\
\text { - short-term counseling }\end{array}$ \\
\hline
\end{tabular}




\section{Continued}

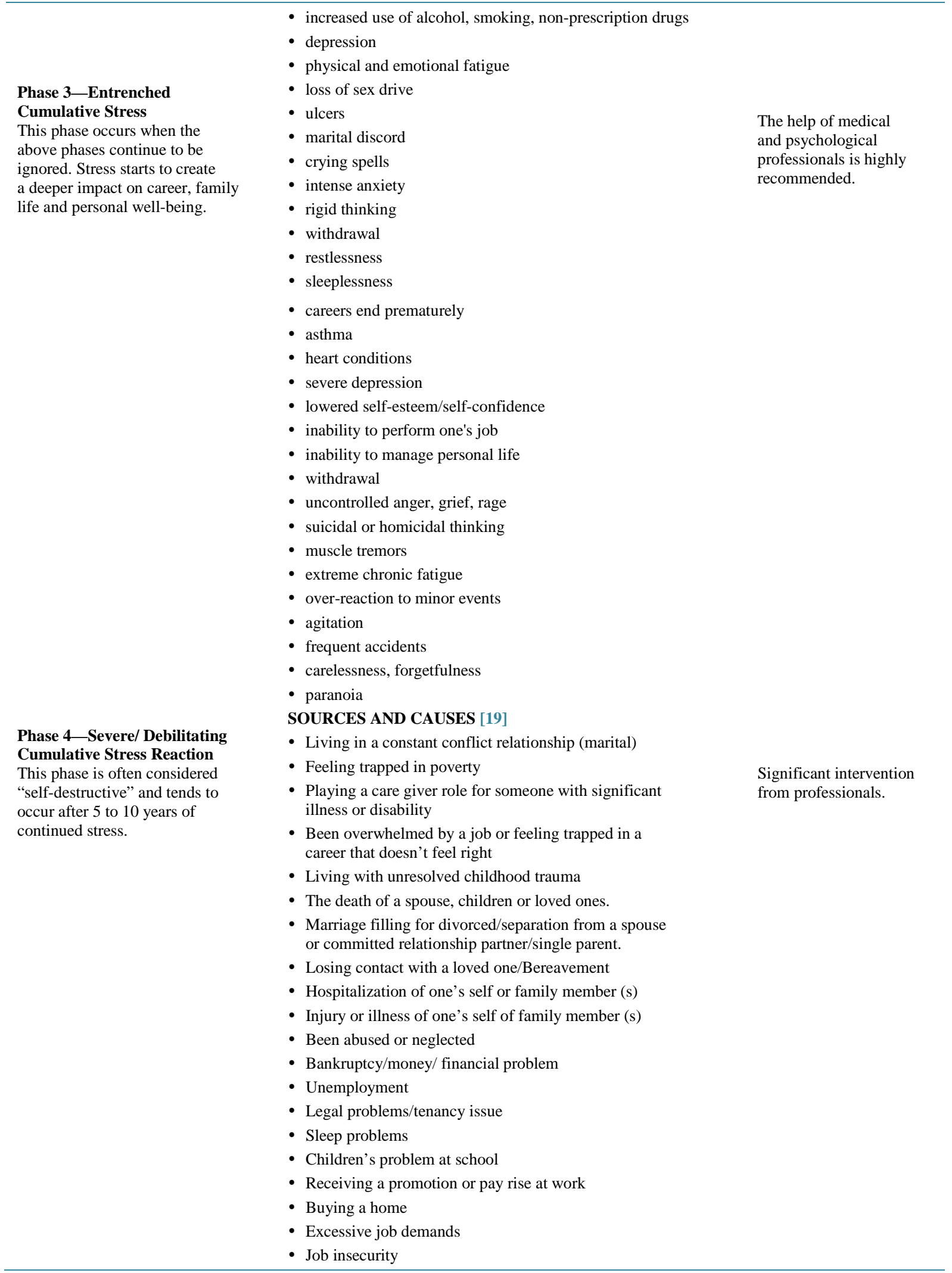




\section{Continued}

Phase 4-Severe/ Debilitating Cumulative Stress Reaction This phase is often considered "self-destructive" and tends to occur after 5 to 10 years of continued stress.
- Conflict with team mates and supervisors

- Lack of necessary training to perform a task (job)

- Mobility fears (phobias) (commuting and travel schedules)

- Traffic transportation

- Repetitive thought patterns

- Worrying about future events

- Unrealistic, and perfectionist expectations

- Over scheduling

- Failing to be assertive

- Procrastination or failing to plan ahead

- Demands-Employees indicate that they are not able to cope with demands of their job.

- Control—Employees indicate that they are not able to have a say about the way they do their work

- Support-Employees indicate that they receive adequate information and support from their colleagues and superiors.

- Relationships-Employees indicate that they are subjected to unacceptable behaviors, Bullying and harassment at work.

- Role-Employees indicate that they don't understand their role and responsibility. There is role confusion.

- Change-Employees complain that the organizations do not carry them along frequently when there is an organizational change.

- Career Development-under-over promotion, career development opportunities

- Organizational structure/climate-favoritism in a place of meritocracy

Significant intervention from professionals.

- Work life balance-career and family (father working, mothe working, their problem taking care of the home front children)

- Financial state-

- Unrealistic expectation

- Ridged thinking, lack of flexibility

- All or nothing attitude

- School and exams

- Demands from boss

- Demands from spouse

- Extended family pressures

- Organizational affiliations pressure

- Accidents and disasters-land, air, water

- Armed robbery attacks

- Kidnapping experience

- Security force brutality—(police, army)

- Task force brutality-(LASTMA, KAI, V.I.O Road safety)

- Hoodlums activities-(Area boys, Opc, Agbero)

- Unfulfilled dreams

- Fuel scarcity

- Protests and strikes

- Relocation—wives/husband's burden during relocation. [3] [19] [20]

\section{Stress and Physiology}

This gives insight on how an organism responds to stress and also a body's method of reacting to challenge by activating the nervous system. This represents a wide range of physical responses occurring as a direct effect of a stress or causing an upset in the homeostasis of the body. Upon immediate disruption of either physiological or physical equilibrium the body responds by stimulating the nervous, endocrine and immune system. The reaction of these systems causes a number of physical changes that have both short and long term effects on the body [17] [21]. 


\section{BIOLOGICAL NEED FOR EQUIIBRUM BY THE BODY}

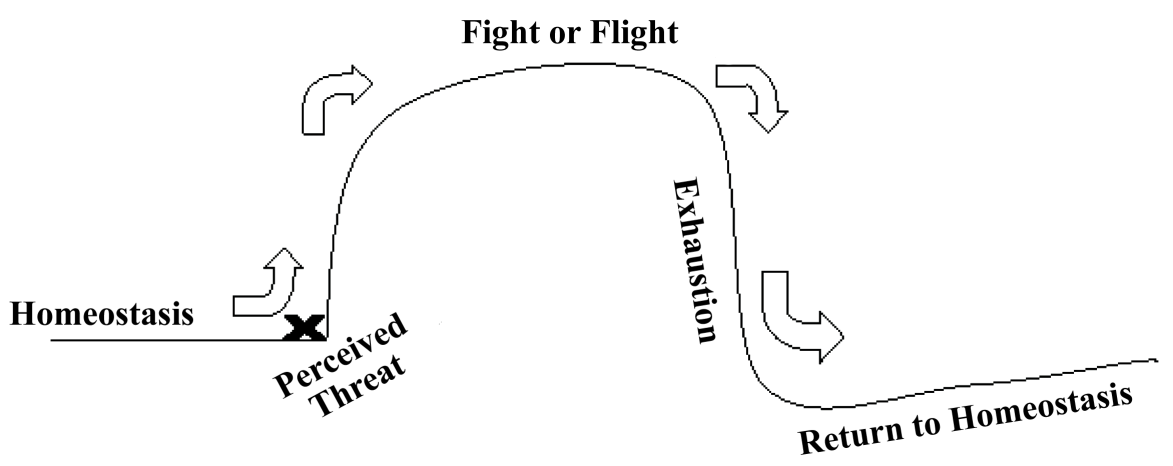

Most biochemical process strive to maintain equilibrium (homeostasis) a steady state that exists more as an achievable condition. Internal and external stimuli continually disrupt homeostasis.

Biology attempts to explain stress as a product of stimulus response. The central nervous system (brain and spinal cord) play a crucial role in the body related mechanism. The central nervous system works closely with the body endocrine system to regulate these mechanisms. The sympathetic nervous system becomes primarily active during a stress response regulating many of the body physiological functions in ways that ought to make an organism more adaptive to its environment [22].

\section{Effects of Stress on the Immune System}

When the equilibrium of various hormones is altered the effect of these changes can be detrimental to the immune system. Stress affects the immune system in many ways. The immune systems protect the body from viruses, bacteria and anything that is different or that the body does not recognize. The immune sees these intruders and it sends message to attack. The white blood cells, leukocytes are very important to the immune system. When an individual is stressed or going through a stressful experience the immune systems starts to produce natural killer cells and cytokine. When level of cytokines are higher they combat infections and the brain gets communicated that the body is ill and it produces symptoms as if the individual was ill. It also causes cardiovascular disease, musculoskeletal disorders, work place injury [6] [17] [18].

\section{Stress, Mental Health and Burn out}

By stress and mental health, we are exploring the effect of stress on an individual's emotional, psychological and physiological well being, the body reaction, loss of mental energy [3] [23].

\section{Cost of Stress}

Cost of Stress includes: absenteeism, litigation, grievances, accidents, errors of judgment and action, conflict and interpersonal problem, violence, customer service problems, resistance to change, no time to do it right, loss of intellectual capital, loss of vitality, suicide, drugs /alcohol abuse, sickness—aging [8] [15] [24] [25].

\section{Management of Stress}

Knowing what you find stressful, practice the following: Alter, accept, adapt, become assertive to the stressful event, create a stress diary, start managing your own life style, practice relaxation techniques such as deep relaxation technique, mental relaxation (five to ten minutes), number countdown (one to ten), physical exercise, express your feelings (ventilation), sleep and rest, good nutrition, engage in creativity and other alternatives [10] [11] [26]-[31].

\section{References}

[1] Jones, F., Bright, J. and Clow, A. (2001) Stress: Myth, Theory, and Research. Pearson Education, New York, 4.

[2] Gibbons, C. (2012) Stress, Positive Psychology and the National Student Survey. Psychology Teaching Review, 18, 22-30. 
[3] Fullagar, C.J., Knight, P.A. and Sovern, H.S. (2013) Challenge/Skill Balance, Flow, and Performance Anxiety. Applied Psychology: An International Review, 62, 236-259. http://dx.doi.org/10.1111/j.1464-0597.2012.00494.X

[4] Selye, H. (1983) The Stress Concept: Past, Present and Future. In: Cooper, C.L., Ed., Stress Research Issues for the Eighties, John Wiley \& Sons, New York, 1-20.

[5] Selye, H. (1974) Stress without Distress. J.B. Lippincott Company, Philadelphia, 171.

[6] Kobasa, S.C. (1982) The Hardy Personality: Toward a Social Psychology of Stress and Health. In: Sanders, G.S. and Suls, J., Eds., Social Psychology of Health and Illness, Lawrence Erlbaum Assoc., Hillsdale, 1-25.

[7] Stressor. Collins English Dictionary-Complete \& Unabridged 11th Edition. Retrieved September 20, 2012 from CollinsDictionary.com.

[8] Cohen, S. and Wills, T.A. (1985) Stress, Social Support, and the Buffering Hypothesis. Psychological Bulletin, 98, 310-357. http://dx.doi.org/10.1037/0033-2909.98.2.310

[9] Cohen, S., Frank, E., Doyle, W.J., Skoner, D.P., Rabin, B.S. and Gwaltney Jr., J.M. (1998) Types of Stressors That Increase Susceptibility to the Common Cold in Healthy Adults. Health Psychology, 17, 214-223. http://dx.doi.org/10.1037/0278-6133.17.3.214

[10] Folkman, S. and Moskowitz, J. (2000) Stress, Positive Emotion, and Coping. Current Directions in Psychological Science, 9, 115-118. http://dx.doi.org/10.1111/1467-8721.00073

[11] Fevre, M.L., Kolt, G.S. and Matheny, J. (2006) Eustress, Distress and Their Interpretation in Primary and Secondary Occupational Stress Management Interventions: Which Way First? Journal of Managerial Psychology, 21, 547-565. http://dx.doi.org/10.1108/02683940610684391

[12] Levo, L.M. (2003) Understanding Defense Mechanisms. Lukenotes, 7.

[13] Hargrove, M.B., Nelson, D.L. and Cooper, C.L. (2013) Generating Eustress by Challenging Employees: Helping People Savor Their Work. Organizational Dynamics, 42, 61-69. http://dx.doi.org/10.1016/j.orgdyn.2012.12.008

[14] Schneiderman, N., Ironson, G. and Siegel, S.D. (2005) Stress and Health: Psychological, Behavioral, and Biological Determinants. Annual Review of Clinical Psychology, 1, 607-628. http://dx.doi.org/10.1146/annurev.clinpsy.1.102803.144141

[15] Greubel, J. and Kecklund, G. (2011) The Impact of Organizational Changes on Work Stress, Sleep, Recovery and Health. Industrial Health, 49, 353-364.

[16] Schneiderman, N., Ironson, G. and Siegel, S.D. (2005) Stress and Health: Psychological, Behavioral, and Biological Determinants. Annual Review of Clinical Psychology, 1, 607-628. http://dx.doi.org/10.1146/annurev.clinpsy.1.102803.144141

[17] Herbert, T.B. and Cohen, S. (1993) Stress and Immunity in Humans: A Meta-Analytic Review. Psychosomatic Medicine, 55, 364-379. http://dx.doi.org/10.1097/00006842-199307000-00004

[18] Kemeny, M.E. (2003) The Psychobiology of Stress. Current Directions in Psychological Science, 12, 124-129. http://dx.doi.org/10.1111/1467-8721.01246

[19] Cohen, S., Janicki-Deverts, D. and Miller, G.E. (2007) Psychological Stress and Disease. JAMA, 298, 1685-1687. http://dx.doi.org/10.1001/jama.298.14.1685

[20] Campbell, J. (1983) Ambient Stressors. Environment and Behavior, 15, 355-380. http://dx.doi.org/10.1177/0013916583153005

[21] Ogden, J. (2007) Health Psychology: A Textbook. 4th Edition, McGraw-Hill, New York, 281-282.

[22] Miller, G., Chen, E. and Cole, S.W. (2009) Health Psychology: Developing Biologically Plausible Models Linking the Social World and Physical Health. Annual Review of Psychology, 60, 501-524. http://dx.doi.org/10.1146/annurev.psych.60.110707.163551

[23] Selye, H. (1975) Implications of Stress Concept. New York State Journal of Medicine, 75, 2139-2145.

[24] Colman, A.M. (2009) “Displacement”: A Dictionary of Psychology. Oxford University Press, Oxford.

[25] Collingwood, J. (2007) The Physical Effects of Long-Term Stress. Psych Central. http://psychcentral.com/lib/the-physical-effects-of-long-term-stress/000935

[26] Adapted from DSM-IV Adaptive Functioning Scale, APA, 1994.

[27] Valliant, G.E. (2000) Adaptive Mental Mechanisms. American Psychologist, 55, 89-98. http://dx.doi.org/10.1037/0003-066X.55.1.89

[28] Shishehgar, S. (2013) The Relationship of Social Support and Quality of Life with the Level of Stress in Pregnant Women Using the PATH Model. Iranian Red Crescent Medical Journal, 15, 560-565. http://dx.doi.org/10.5812/ircmj.12174 
[29] Uchino, B.N. (2009) Understanding the Links between Social Support and Physical Health: A Life-Span Perspective with Emphasis on the Separability of Perceived and Received Support. Perspectives on Psychological Science, 4, 236255. http://dx.doi.org/10.1111/j.1745-6924.2009.01122.x

[30] Robertson, D. (2012) Build Your Resilience. Hodder, London.

[31] Sutarto, A.P., Wahab, M.N. and Zin, N.M. (2012) Resonant Breathing Biofeedback Training for Stress Reduction among Manufacturing Operators. International Journal of Occupational Safety and Ergonomics, 18, 549-561. http://dx.doi.org/10.1080/10803548.2012.11076959 